\title{
PENGARUH MOTIVASI TERHADAP PRESTASI KERJA KARYAWAN
}

Suparno

\begin{abstract}
The purpose of this study was to determine the effect of motivation on employee performance of PT Pos Type C Manado. This research uses descriptive quantitative approach to measure and influence the relationship between motivation and job performance. The population in this study amounted to 200 employees, with a simple random sampling which amounts to 50 respondents. Using correlation and regression analysis. The analysis showed that there is a fairly strong correlation between motivation and job performance, as well as the motivation has a positive impact with work performance. Thus, the motivation has a strong relationship with the work performance of employees at PT Pos Indonesia Type C Manado.
\end{abstract}

Keywords: Motivation, Job Performance

\section{PENDAHULUAN}

Suatu perusahaan dalam melaksanakan kegiatannya, akan berusaha untuk mencapai tujuan yang telah ditetapkan sebelumnya. Satu hal yang penting yaitu bahwa keberhasilan berbagai aktivitas didalam perusahaan dalam mencapai tujuan bukan hanya tergantung pada keunggulan teknologi, dana operasi yang tersedia, sarana dan prasarana yang dimiliki, melainkan juga tergantung pada aspek sumber daya manusia. Sumber daya manusia yang dimaksud adalah orang-orang yang memberikan tenaga, pikiran, bakat, kreativitas dan usahanya pada perusahaan.

Setiap perusahaan berupaya untuk mendapatkan karyawan yang pernah terlibat dalam kegiatan organisasi atau perusahaan, sehingga dapat memberikan kontribusi pada pencapaian target yang telah ditetapkan perusahaan. Target yang dicapai karyawan merupakan prestasi kerja yang dapat diukur secara kualitas maupun kuantitas yang dicapai persatuan periode waktu dalam melaksanakan tugas kerja sesuai dengan tanggung jawab yang diberikan. Setiap organisasi atau perusahaan dalam melaksanakan program selalu diarahkan untuk mencapai efisiensi dan efektivitas untuk mencapai tujuan perusahaan. Salah satu caranya adalah dengan meningkatkan prestasi kerja karyawan.

Rumusan masalah dalam penelitian ini adalah bagaimana pengaruh motivasi terhadap prestasi kerja karyawan pada kantor pos Indonesia Tipe C Manado? Sedangkan 
tujuan yang penelitian adalah untuk mengetahui pengaruh motivasi terhadap prestasi kerja karyawan pada Kantor Pos Tipe C Manado.

Teori motivasi Abraham Maslow dalam Robbins (2006) mengatakan bahwa di dalam diri semua manusia bersemayam lima jenjang kebutuhan, yaitu sebagai berikut : (1) Fisiologis, rasa lapar, haus, perlindungan (pakaian dan perumahan), seks, dan kebutuhan jasmani lain; (2) Keamanan, keselamatan dan perlindungan terhadap kerugian fisik dan emosional; (3) Sosial, mencakup kasih sayang, rasa memiliki, diterima baik, dan persahabatan; (4) Penghargaan, mencakup faktor penghormatan diri seperti harga diri, otonomi, dan prestasi; serta faktor penghormatan dari luar seperti misalnya status, pengakuan, dan perhatian; (5) Aktualisasi diri, dorongan untuk menjadi seseorang atau sesuatu sesuai ambisinya

Herzberg menjelaskan teori dua faktor motivasi yaitu: Hygiene Factors yang meliputi gaji, kehidupan pribadi, kualitas supervisi, kondisi kerja, jaminan kerja, hubungan antar pribadi, kebijaksanaan dan administrasi perusahaan atau motivasi eksternal. Motivation Factors, yang dikaitkan dengan isi pekerjaan mencakup keberhasilan, pengakuan, pekerjaan yang menantang, peningkatan dan pertumbuhan dalam pekerjaan atau motivasi internal (Koontz, 1990).

Teori Motivasi Klasik, Teori motivasi ini diungkapkan oleh Frederick Taylor yang menyatakan bahwa pekerja hanya termotivasi semata-mata karena uang. Konsep ini menyatakan bahwa seseorang akan menurun semangat kerjanya bila upah yang diterima dirasa terlalu sedikit atau tidak sebanding dengan pekerjaan yang harus dilakukan (Griffin, 1998).

Teori X dan Y, Teori ini dikemukakan oleh Douglas McGregor. Ia membedakan 2 tipe pekerja yaitu $\mathrm{X}$ dan $\mathrm{Y}$. a. Teori X, menyatakan bahwa orang-orang sesungguhnya malas dan tidak mau bekerja sama. b. Teori Y, menyatakan bahwa orang-orang sesungguhnya energik, berorientasi kepada perkembangan, memotivasi diri sendiri, dan tertarik untuk menjadi produktif (Griffin, 1998).

Stoner (1996) menyebutkan faktor- faktor motivasi kerja dalam organisasi ialah: (1) Karakteristik Individu yang berbeda; (2) Karakteristik pekerjaan yang berbeda; (3) Karakteristik organisasi. Menurut Hasibuan (2002) Faktor-faktor yang mempengaruhi 
motivasi kerja: (1) Upah; (2) Situasi kerja; (3) Kondisi kerja yang akan mendorong semangat kerja karyawan; (4) Fasilitas kerja; (5) Sikap manajemen terhadap karyawan; (6) Sikap antar teman sejawat; (7) Kebutuhan karyawan berprestasi; (8) Pelatihan; (9) Insentif; (10) Promosi; (11) Kebutuhan untuk meningkatkan kemampuan.

Karyawan dalam menjalankan tugas dan pekerjaan dengan baik memerlukan motivasi, tugas pemimpin dalam hal ini ialah membuat lingkungan kerja yang baik sedemikian rupa sehingga karyawan dalam organisasi termotivasi dengan sendirinya (Mas'ud, 2004). Untuk itu diperlukan pemahaman motivasi yang baik, baik dalam diri bawahan atau karyawan guna membantu dalam meningkatkan produktifitas kerjanya. Pada dasarnya motivasi seseorang ditentukan oleh intensitas motifnya mengartikan motivasi yakni dorongan kebutuhan, keinginan, dan rangsangan (Cahyono dan Suharto, 2005). Pendapat lain melihat motivasi sebagai daya pendorong atau tenaga pendorong seseorang yang mendorong seseorang untuk bertindak (Martoyo, 2000). Jadi dengan adanya motif dalam diri seseorang maka akan menimbulkan motivasi.

Motivasi sendiri adalah reaksi yang timbul dari dalam diri seseorang sebagai dorongan karena adanya rangsangan dari luar yang mempengaruhi untuk memenuhi tujuan tertentu (Suranta, 2002). Motivasi merupakan kondisi yang berpengaruh membangkitkan, mengarahkan, dan memelihara perilaku yang berhubungan dengan lingungan kerja (Mangkunegara, 2005). motivasi merupakan keinginan untuk melakukan sesuatu sebagai kesediaan untuk megeluarkan tingkat upaya yang tinggi untuk tujuantujuan organisasi, yang dikondisikan oleh kemampuan upaya itu untuk memenuhi suatu kebutuhan individual (Robbins, 2008).

Pandangan lain melihat motivasi sebagai proses atau faktor yang mendorong orang untuk bertindak atau berperilaku dengan cara tertentu, dengan dasar manusia mudah diberikan motivasi karena jika kebutuhannya terpenuhi maka seseorang akan mempunyai

Dalam pemberian dorongan sebagai bentuk motivasi kerja kepada bawahan penting dilakukan untuk meningkatkan prestasi karyawan. motivasi berasal dari kata latin movere yang berarti dorongan atau pemberian daya penggerak yang menciptakan kegairahan kerja seseorang agar mereka mau bekerja sama, bekerja efektif, dan 
terintegrasi dengan segala daya upayanya untuk mencapai kepuasan (Malayu, 2005). Motivasi merupakan faktor yang kehadirannya dapat menimbulkan kepuasan kerja, dan kehidupan berorganisasi, motivasi yang tinggi untuk menyelesaikan tugas-tugas yang diberikan (Zainun, 2004). Selanjutnya motivasi itu merupakan faktor psikologis yang menunjukkan minat individu terhadap pekerjaan, rasa puas, dan ikut bertanggung jawab terhadap aktivitas atau pekerjaan yang dilakukan (Masrukhin dan Waridin, 2006).

Prestasi kerja adalah suatu metode bagi manajemen untuk membuat suatu analisa yang adil dan jujur tentang nilai karyawan bagi organisasi (Manulang (2001). Kinerja (performance) diistilahkan sebagai prestasi kerja yaitu proses melalui evaluasi organisasi atau menilai prestasi kerja karyawan (Handoko, 2002). Prestasi kerja didefinisikan sebagai "Performance is defined as the record of outcome produced on a specified job function or activity during a specified time period" (Prestasi kerja didefinisikan sebagai catatan dari hasil- hasil yang diperoleh melalui fungsi-fungsi pekerjaan tertentu (Bernardin dan Russel, 1993).

Penilaian prestasi kerja adalah penting dalam suatu organisasi dalam rangka pengembangan SDM. Kegiatan ini dapat memperbaiki keputusan manajer dan memberikan umpan balik kepada karyawan tentang kegiatan mereka" (Notoatmodjo, 1988). Penilaian kinerja (performance appraisal) memainkan peranan yang sangat penting dalam peningkatan motivasi di tempat kerja. Karyawan menginginkan dan memerlukan balikan yang berkenan dengan prestasi mereka dan penilaian menyediakan kesempatan untuk memberikan balikan kepada mereka. Jika kinerja tidak sesuai dengan standar, maka penilaian memberikan kesempatan untuk meninjau kemajuan karyawan dan untuk menyusun rencana peningkatan kinerja. Penilaian kinerja merupakan upaya membandingkan prestasi aktual karyawan dengan prestasi kerja dengan yang diharapkan darinya.

Menurut Mangkunegara (2000 faktor- faktor yang mempengaruhi prestasi kerja adalah: (1) Faktor kemampuan, meliputi kerja sama, keterampilan dan kreativitas, pengalaman dalam bekerja, tingkat ketelitian dan komunikasi; (2) Faktor Motivasi, meliputi kedisiplinan, pendidikan, dan semangat kerja dan kepribadian. 
Manajemen Perusahaan harus mengetahui prestasi kerja bawahannya agar ia dapat mengambil keputusan yang tepat menyangkut karyawannya. Perusahaan perlu memahami adanya faktor-faktor yang mempengaruhi motivasi kerja untuk dapat membantu meningkatkan prestasi kerja karyawannya. Faktor-faktor tersebut perlu dikaji mengapa ada karyawan yang rajin sementara disisi lain ada karyawan yang malas dan kurang bersemangat. Pemimpin perlu mengetahui prestasi kerja karyawannya agar ia dapat memperlakukan karyawannya secara adil dalam hal seperti promosi, gaji/upah, bonus dan sebagainya. Dengan memahami prestasi kerja bawahannya, pemimpin dapat memberikan tugas yang sesuai dengan kemampuannya, dan memotivasi karyawannya sehingga prestasi kerjanya dapat ditingkatkan. Salah satu cara manajemen untuk meningkatkan prestasi kerja, salah satunya melalui pemberian dorongan atau motivasi (Mathis dan Jackson, 2000).

Bila Perumusan kebijaksanaan motivasi telah tepat, baik dalam aspek keadilan maupun kelayakannya maka karyawan akan merasa puas dan termotivasi untuk melaksanakan berbagai kegiatan yang berhubungan dengan pencapaian perusahaan, para karyawan akan sendirinya melakukan tugas dan tanggung jawabnya secara efektif dan efisien. Sebaliknya, bila rasa keadilan dan kelayakan tidak terpenuhi akan menyebabkan karyawan mengeluh, menimbulkan ketidakpuasan kerja yang kemudian berdampak pada kemerosotan semangat kerja yang pada gilirannya menyebabkan prestasi kerja karyawan akan merosot pula. Dengan kata lain, suatu sistem Motivasi yang baik adalah sistem yang mampu menjamin kepuasan para anggota organisasi, sehingga memungkinkan untuk memperoleh, memelihara dan memperkerjakan sejumlah orang yang produktif bagi kepentingan organisasi.

Ketika pemberian motivasi berjalan dengan lancar dan sesuai dengan perencanaannya, maka tahapan selanjutnya yang diharapkan akan terjadi adalah peningkatan prestasi kerja karyawan. Ketika prestasi kerja karyawan telah tercapai maka perusahaan dapat mengukur sejauh mana peningkatan kinerja yang mereka capai secara maksimal dan tujuan perusahaan akan terpenuhi.

\section{METODE PENELITIAN}


Penelitian ini merupakan penelitian deskriptif Kuantitatif, dengan menggunakan pendekatan korelasi dan regresi sederhana, untuk melihat hubungan antar variabel serta untuk mengukur besarnya pengaruh yang terjadi pada variabel tersebut. Yang menjadi Lokasi penelitian ini adalah Kantor Pos Tipe C, Manado.

Adapun jenis data yang digunakan dalam penelitian ini adalah: (1) Data Kualitatif adalah data yang bukan dalam bentuk angka- angka atau tidak dapat dihitung, dan diperoleh dari hasil wawancara dengan pimpinan perusahaan dan karyawan dalam perusahaan serta informasi-informasi yang diperoleh dari pihak lain yang berkaitan dengan masalah yang diteliti; (2) Data Kuantitatif adalah data yang diperoleh dalam bentuk angka-angka yang dapat dihitung, yang diperoleh dari kuesioner yang dibagikan dan berhubungan dengan masalah yang diteliti.

Sumber data yang digunakan dalam penelitian ini terdiri dari dua macam yaitu data primer dan data sekunder. Proses pengumpulan data yang diperlukan dalam penelitian ini melalui pengamatan langsung pada perusahaan yang bersangkutan, baik melalui observasi, penyebaran kuesioner kepada para pegawai, dan wawancara untuk mendapatkan informasi tentang motivasi dan Prestasi karyawan. Yang menjadi populasi dalam penelitian ini adalah Karyawan Kantor Pos Tipe C Manado sebanyak 200 karyawan. Sedangkan pengambilan sampel sebanyak 50 responden sebagai karyawan tetap yang sudah lama bekerja dan mempunyai pengalaman yang mendukung dalam penelitian ini.

Teknik analisis data terdiri dari: (1) Koefisien determinasi dan korelasi, koefisien korelasi digunakan untuk mengetahui hubungan variabel bebas terhadap variabel terikat dengan mengikuti formula Pearson. Koefisien determinasi atau koefisien penentu (KP) digunakan untuk mengetahui pengaruh seluruh variabel bebas terhadap variabel terikat; (2) Analisis Regresi Sederhana, digunakan untuk mengetahui besarnya pengaruh variabel independen terhadap variabel dependen.

\section{HASIL DAN PEMBAHASAN}

Hasil Penelitian 
Koefisien korelasi produk momen (r) akan menunjukan derajat korelasi atau tingkat keeratan hubungan antara variabel bebas motivasi dengan variabel terikat prestasi kerja karyawan. Hasil perhitungan nilai koefisien determinasi memberikan petunjuk tentang hubungan motivasi dengan prestasi kerja karyawan yaitu sebesar $r=0,685$. Dengan nilai koefisien ini bertanda positif, sehingga hal itu memberikan petunjuk adanya hubungan erat antara motivasi terhadap prestasi kerja karyawan Kantor Pos Tipe C Manado. Untuk dapat memberikan interpretasi terhadap hubungan antara motivasi dengan prestasi kerja dilakukan uji koefisien determinasi (KP).

Nilai koefisien korelasi (r) adalah sebesar 0,685 dan nilai koefisien determinasi (koefisien penentu) $\mathrm{r}^{2}$ sebesar 0,465 atau 46,5\%. Ini memberi petunjuk bahwa hubungan motivasi dan prestasi kerja karyawan ternyata cukup kuat, yaitu sebesar 0,685. Besar penentu (determinasi) yakni 0,465 atau $46,5 \%$ memberi petunjuk bahwa prestasi kerja karyawan sebanyak 46,5\% dipengaruhi oleh motivasi, sedangkan 53,5\% lainnya ditentukan oleh faktor lain yang tidak di teliti dalam penelitian ini. Beberapa faktor yang tidak di teliti, antara lain gaya kepemimpinan, lingkungan kerja, stres kerja, teknologi dan informasi, kompensasi, dan lain sebagainya.

Dari hasil analisis regresi diperoleh nilai konstanta (a) sebesar 31,20 menunjukkan besarnya variabel pemberian motivasi yang tidak dipengaruhi oleh prestasi kerja atau dapat diartikan pada saat nilai motivasi sebesar 0 , maka prestasi kerja karyawan sebesar 31.20. Koefisien regresi sebesar 0,28 berarti motivasi mempunyai hubungan positif atau searah dengan prestasi kerja, karena koefisien regresi bernilai positif. Setiap peningkatan 1 satuan motivasi maka akan berpengaruh terhadap peningkatan prestasi kerja karyawan sebesar 0,28 satuan. Begitu juga sebaliknya setiap penurunan motivasi sebesar 1 satuan akan berpengaruh terhadap penurunan prestasi kerja karyawan sebesar 0,28 satuan.

Sebagai mana telah disebutkan dalam metode penilitian di atas bahwa pengujian signifikan korelasi variabel motivasi dengan prestasi kerja karyawan dengan menggunakan uji statistic-t. untuk mengetahui taraf signifikan hubungan antara motivasi dengan prestasi kerja. Hipotesis untuk uji keberartian korelasi ini adalah ada hubungan yang nyata antara motivasi dengan prestasi kerja karyawan. Hasil analisis uji t mendapati 
nilai thitung $=6,475$, jika $\alpha=0,01$ maka dengan $\mathrm{dk}=50-2=48$, dari daftar distribusi di dapat $\mathrm{t}_{0,99}(48)=2,407$. Jelas bahwa nilai analisis $\mathrm{t}$ hitung $=6,475$ lebih besar dari pada nilai t pada taraf sifnifikan $=2,407,(6,475>2,407)$. Dengan demikian menerima Hipotesis yang menyatakan ada pengaruh motivasi terhadap prestasi kerja karyawan pada Karyawan PT Kantor Pos Tipe C Manado.

Pembahasan

Secara nyata berdasarkan hasil penelitian menunjukan bahwa secara statistik hipotesis yang diajukan terdukung oleh teori sebelumnya. Dari data pada pengujian hipotesis, dapat disimpulkan bahwa hipotesis mempresentasikan pengaruh positif dan signifikan Motivasi terhadap Prestasi Kerja karyawan. Hal ini berarti pemberian motivasi yang efektif mempengaruhi para karyawannya untuk mempunyai optimisme yang lebih besar, rasa percaya diri, serta komitmen kepada tujuan dan misi organisasi sehingga prestasi kerja lebih meningkat dan produktifitas kerja karyawan lebih maksimal.

Motivasi yang efektif seperti memberikan gaji, insentif, bonus, kompensasi, THR, tempat kerja yang aman, kodisi kerja yang layak, tersedianya mobil dinas, rumah dinas, tujangan pensiun, tunjangan kesehatan dan keselamatan kerja dan promosi sehingga karyawan termotivasi untuk bekerja dengan giat dan semangat sesuai dengan ketrampilan dan kemampuan yang dimiliki. motivasi yang efektif seperti ini tidak di pungkiri lagi prestasi karyawan akan semakin baik, gairah semangat kerja semakin meningkat dengan rajin ke kantor, menyelesaikan pekerjaan sesuai target yang ditentukan perusahaan dan lain-lain. Dengan demikian motivasi kepada karyawan berpengaruh terhadap Prestasi Kerja karyawan PT Kantor Pos Tipe C

Manado. Dari hasil analisis di dapat nilai koefisien produk moment yaitu sebesar 0,685 yang menunjukan adanya korelasi atau hubungan yang signifikan antara Motivasi terhadap Prestasi Kerja karyawan. Sehingga Motivasi mempunyai pengaruh sebesar 46,5\% terhadap Prestasi Kerja karyawan dan 53,5 \% lainnya di tentukan oleh factorfaktor yang tidak di teliti pada penelitian ini. Pada analisis regresi Nilai konstanta (a) sebesar 31,20 menunjukkan besarnya variabel pemberian motivasi yang tidak 
dipengaruhi oleh prestasi kerja atau dapat diartikan pada saat nilai motivasi sebesar 0 , maka prestasi kerja karyawan sebesar 31.20. Dan koefisien regresi sebesar 0,28 berarti motivasi mempunyai hubungan positif atau searah dengan prestasi kerja, karena koefisien regresi bernilai positif. Setiap peningkatan 1 satuan motivasi maka akan berpengaruh terhadap peningkatan prestasi kerja karyawan sebesar 0,215 satuan. Begitu juga sebaliknya setiap penurunan motivasi sebesar 1 satuan akan berpengaruh terhadap penurunan prestasi kerja karyawan sebesar 0,215 satuan.

Dengan demikian, hasil pengujian adalah menolak Ho yang menyatakan "tidak ada hubungan antara motivasi dengan prestasi kerja " dan menerima $\mathrm{H}_{\mathrm{A}}$ yang menyatakan "ada hubungan antara motivasi dengan prestasi kerja karyawan PT Kantor Pos Tipe C Manado”. Dengan hasil ini berarti motivasi memiliki pengaruh yang cukup kuat dan merupakan faktor yang penting terhadap peningkatan prestasi kerja karyawan PTKantor Pos Tipe C Manado.

\section{KESIMPULAN}

Berdasarkan hasil penelitian serta pembahasan yang telah dikemukakan terdahulu, maka bab penutup ini penulis dapat memberikan kesimpulan sebagai berikut: (1) Motivasi berpengaruh signifikan terhadap prestasi kerja karyawan pada PT Kantor Pos Tipe C. Hal ini di karenakan motivasi merupakan faktor kuat untuk mendorong semangat atau gairah karyawan untuk melalukan kegiatan tertentu dalam memaksimalkan kinerja dan meningkatkan prestasi kerjanya; (2) Hasil analisis deskriptif menunjukan bahwa secara umum faktor motivasi,dan prestasi kerja karyawan Pada PT Kantor Pos Tipe C Manado mendapat penilaian yang sangat baik; (3) Dalam memotivasi para karyawan, pimpinan perusahaan hendaknya menyediakan peralatan, menciptakan suasana pekerjaan dengan baik, dan memberikan kesempatan untuk promosi, dengan demikian, memungkinkan para bawahan meningkatan semangat kerjanya untuk mencapai tujuan perusahaan yang diinginkannya, yang merupakan daya penggerak untuk memotivasikan karyawan dalam mengerahkan semua potensi yang dimilikinya. 


\section{DAFTAR PUSTAKA}

Arikunto, Suharsimi. 2004. Prosedur Penelitian :Suatu Pendekatan Praktek. jilid 2, PT Rhineka Cipta Jakarta.

Cooper, Donald R, dan William, Emory. 1996. Metode Penelitian Bisnis, Jilid Satu, Edisi Kelim, Erlangga, Jakarta.

Gomes, F. Cardoso. 2003. Manajemen Sumber Daya Manusia. Edisi 2. Yogyakarta. ANDI

Handoko, T. H. 1992. Manajemen Personalia dan Sumber Daya Manusia. Yogyakarta, BPFE.

Heidrajrachman dan Husnan, Suad. 2000. Manajemen Personalia. BPFE, Yogyakarta.

Hasibuan Sayuti. 2002. Manajemen Sumber Daya Manusia. Muhammadiyah University Press, Surakarta.

Indriantoro, Nur dan Bambang, Supomo. 2002. Metode Penelitian Bisnis. Edisi Pertama Cetakan Pertama. Penerbit BPFE, Yogyakarta.

Malayu,S.P. Hasibuan. 2006. Manajemen Sumber Daya Manusia. Edisi Revisi, Cetakan Kedelapan. PT. Bumi Aksara, Jakarta.

Mankunegara, Anwar Prabu. 2001. Manajemen Sumber daya Manusia Perusahaan, PT Remaja Rosdakarya, Bandung.

Mathis L.Robert dan Jackson H. John. 2002. Manajemen Sumber Daya Manusia, Penerbit Salemba Empat, Jakarta.

Mulyono Mauled. 2004. Dasar-dasar Manajemen dan Perilaku, jilid 1, edisi ke 5, Erlangga, Jakarta.

Nawawi, Hadadari, H. 2001. Manajemen Sumber Daya Manusia. Edisi 1, Cetakan Ke 4. Gadjah Mada Press, Yogyakarta.

Nawawi, H, Handari. 2001. Manajemen Sumber Daya Manusia, Untuk Bisnis yang kompetitif. GajahMada University Press, Yogyakarta.

Sugiono. 2003. Metode Penelitian Administrasi. Penerbit Alfabeta, Bandung.

Siagian S. P. 2003. Teori dan Praktek Kepemimpinan. Penerbit Rineka Cipta, Jakarta. 
Riduan. 2003. Dasar-Dasar Statistika, Alfabeta, Jakarta.

Riduwan. 2006. Metode dan Teknik Menyusun Tesis, Cetakan 4, Alfabeta, Bandung.

Siagian, S.P. 2003 . Manajemen Sumber Daya Manusia. Edisi 1, Cetakan Kesepuluh. PT. Bumi Aksara, Jakarta.

Simamora H. 1997. Manajemen Sumber Daya Manusia. Edisi ke-2 STIE YKPN, Yogyakarta.

Singarimbun. M \& Effendi.S. 2006. Metode Penelitian Survei, LP3ES, Jakarta.

Sudjana.1992. Metode Statistika, Tarsito, Bandung.

Sugiyono. 2012. Metode penelitian Bisnis, Edisi 1, cetakan ke 16, Alfabeta, Bandung.

Sugiono. 2004. Metode Penelitian Administrasi, Alfabeta, Bandung.

Sulistiyani A.T. dan Rosidah. 2003. Manajemen Sumber Daya Manasusia :Konsep, Teori dan Pengembangan dalam Konteks Organisasi Politik. Graha Ilmu, Yogyakarta.

Triton, P, B. 2009. Mengolah Sumber Daya Manusia, cetakan 1, Oryza, Yogyakarta.

Veithzal, Rivai. 2004. Manajemen Sumber Daya Manusia Untuk Perusahaan. Cetakan Pertama, PT Raja Grafindo. Jakarta. 